\title{
THE EFFECT OF SUPERITEM LEARNING MODEL ON INCREASING STUDENTS LEARNING ACHIEVEMENTS
}

\author{
M Kholidin Maftuh ${ }^{1}$, Dayat Hidayat ${ }^{2}$ \\ ${ }^{1,2}$ Mathematics Education Program Post Graduate IKIP Siliwangi, Cimahi \\ ${ }^{1}$ Simamad.08@gmail.com, ${ }^{2}$ kanghidayat@gmail.com
}

Received: Nov $9^{\text {th }}, 2018$; Accepted: Nov $28^{\text {th }}, 2018$

\begin{abstract}
This study aims to see the influence of super-learning models on student achievement. The aim to be achieved in this study is to determine whether or not the influence of super-learning learning models on quadrilateral learning on improving student learning achievement. The population in this study were Pangkalan 2 junior high school students. Samples were taken using makeshift sample techniques where the entire population was sampled; one class was made into the experimental class namely class VII A; and one class was made into the control class namely class VII B. The method in this study was experimental method. There contained research on students of SMPN 2 Pangkalan Karawang regency class VII with quadrilateral. The instruments in this study were Student Worksheets and achievement tests given at the initial test and final test. Based on the results of the analysis and testing of hypotheses, it was concluded that the use of Superitem learning models had a positive effect on improving student learning achievement, and there were differences in the increase in learning achievement between students who had mathematical learning using super-learning models with students who used mathematics learning conventional learning.
\end{abstract}

Keywords: Superitem Learning Model, Students Learning Achievement

\begin{abstract}
Abstrak
Penelitian ini bertujuan untuk melihat pengaruh model super-learning terhadap prestasi belajar siswa. Tujuan yang ingin dicapai dalam penelitian ini adalah untuk mengetahui ada atau tidaknya pengaruh model pembelajaran super-learning terhadap pembelajaran segiempat terhadap peningkatan prestasi belajar siswa. Populasi dalam penelitian ini adalah siswa SMP Pangkalan 2. Sampel diambil menggunakan teknik sampel sementara di mana seluruh populasi dijadikan sampel; satu kelas dibuat menjadi kelas eksperimen yaitu kelas VII A; dan satu kelas dibuat menjadi kelas kontrol yaitu kelas VII B. Metode dalam penelitian ini adalah metode eksperimen. Di sana terkandung penelitian pada siswa SMPN 2 Kabupaten Pangkalan Karawang kelas VII dengan segiempat. Instrumen dalam penelitian ini adalah Lembar Kerja Siswa dan tes prestasi yang diberikan pada tes awal dan tes akhir. Berdasarkan hasil analisis dan pengujian hipotesis, disimpulkan bahwa penggunaan model pembelajaran Superitem memiliki efek positif pada peningkatan prestasi belajar siswa, dan terdapat perbedaan peningkatan prestasi belajar antara siswa yang memiliki pembelajaran matematika menggunakan super model pembelajaran dengan siswa yang menggunakan pembelajaran matematika pembelajaran konvensional.
\end{abstract}

Kata Kunci: Model Pembelajaran Superitem, Prestasi Belajar Siswa.

How to Cite: Maftuh, M. K., \& Hidayat, D. (2018). The Effect of Superitem Learning Model on Increasing Students Learning Achievement. JIML, 1 (4), 367-373.

\section{INTRODUCTION}

The influence of mathematics on the development of technology that supports the development of culture and human life since the past, present and future will have a very large 
368 Maftuh, \& Hidayat. The Effect of Superitem Learning Model on Increasing Students Learning Achievement

role. Therefore, it is very natural if the mathematical concept is very attached to other subjects such as physics, chemistry, geography, and other lessons.

In the pedagogy process, the teacher expects that the students get the best learning achievement, and the achievements achieved by students are a measure of success obtained by students. While student learning achievement is still low and it really is not an easy job for the teacher as a teacher to improve student learning achievement. Ruseffendi (Hartati, 2013) argued that the success of students learning will be much influenced by the abilities possessed by the teacher. In the pedagogy process, the teacher expects that the students get the best learning achievement. It achieves by students are a measure of success obtained by students

This is a challenge faced by each teacher to improve students learning achievement in the pedagogy process. Many efforts have been made and many successes have been achieved, but the results have not fully provided satisfaction so that it still demands continuous thinking, as well as efforts to solve the problem at hand. It should also be noted that in practice the implementation of learning is not as smooth as expected, it is not the same as the results of planned theories and methods, because many factors greatly influence the success of the pedagogy process (Riyani, 2012).

This is in accordance with what was stated by Ruseffendi (Hartati, 2013), "The success of students learning would be much influenced by the abilities possessed by the teacher, one of the abilities that might be possessed by the teacher was the ability to master the subject matter." An educator must strive so that students in learning not only record and memorize the lessons given, but also must motivate the importance of the lesson in the future, so that students' interest in the material delivered is better.

The exercise of mathematics is a project, questions, problems of construction, application and training given to students. Anthony observed that most mathematical exercises were given only as procedural and accuracy-focused exercises, rarely was the mathematical concept integrated with other concepts and rarely contained questions that required high-level thinking skills. So that, when students are faced with difficult questions, students tend to be lazy to do it (Permatasari, 2014). Then, he negotiated the matter with his teacher.

These obstacles sometimes appear differently in each class and were strongly influenced by the circumstances, situations, and conditions in the class concerned (Pratiwi, Sukestiyarno, \& Asikin, 2014) The most important factor was the ability of the teacher in the teaching and learning process. Biggs and Collis (Yunus, Suyitno, \& Waluyo, 2013) conducted a study of the structure of learning outcomes with tests compiled in the form of Superitems, in their findings suggesting that at each stage or cognitive level there was the same response structured and increased from simple up to the abstract. The structure was called the SOLO taxonomy (Structure of the Observed Learning Outcome). According to Biggs and Collis (Rahma, 2012) based on the quality of the child's response the SOLO stage of the child was classified at four stages or levels.

The study of SOLO was also carried out by Sumarmo (Hartati, 2013). The findings in this study reinforce the belief that in learning, an explanation of mathematical concepts should not be direct to complex or complex concepts, but it must begin with a simple concept. Based on this, Sumarmo provided alternative learning that starts from the simple to the complex, the learning used the exercise of the form of Superitem. 
According to Biggs and Collis, learning using the Superimposed form exercise was learning that started from a simple exercise that increased on a more complex one by paying attention to the SOLO stage of the student (Hartati, 2013). Likewise in learning mathematics, when students try to solve a mathematical problem, it takes confidence, curiosity, resilience, reflection on the way of thinking (Hajar \& Sari, 2018).

\section{METHOD}

The method used the experimental method. This study was conducted to determine the effect of the use of super-learning learning models on students mathematics learning achievement. In carrying out this research, there was a group of students as a group that was deliberately treated by using super-learning. This study was intended to determine the effects of the treatment given to a group, so the designs used were as follows:

1. Accordance with the hypothesis made, in this study there is one group that is needed, namely the experimental class.

2. In the experimental class the learning process uses super-learning learning models.

Schematically, this research design uses a pattern:

\section{$\mathrm{OXO}$}

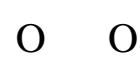

Information:

$\mathrm{O} \quad=$ Pre-test and Post-test

$\mathrm{X}=$ Supritem learning

----- $=$ sample was taken not randomly class

Population is the entire object to be studied. As stated by Sumaatmaja that the overall population of individual symptoms, cases and problems studied is in the study area, all cases, individuals and symptoms in the study area are called the study population or universe (Martono, 2010). In this study, the population was all students of seventh grade Muhammadiyah Junior High School 3 Kertasari Bandung Regency 2018-2019 school year which consists of two classes.

The sample is part of a population that has characteristics, symptoms and characteristics that are the same as the population so that it can represent the population. As stated by Sumaatmaja that samples were part of the population (snippets, examples) that represent the population concerned (Martono, 2010).

As for the sampling using a simple sample technique where all the population is sampled, one class is used as the experimental class, namely class VII A using super-learning and one class is used as the control class VII B class that uses conventional learning. To measure accuracy (validity), regularity (reliability), level of difficulty, and differentiation of the test instrument, then the instrument was tested before the seventh grade students of Junior High School State 2 Pangkalan who had obtained rectangular learning. In analysing the validity, reliability, level of difficulty, and distinguishing power from the results of the trial test the instrument is guided by the analysis as follows: 
370 Maftuh, \& Hidayat. The Effect of Superitem Learning Model on Increasing Students Learning Achievement

Table 1. Characteristics of Instruments of This Study

\begin{tabular}{ccccccc}
\hline $\begin{array}{c}\text { Test and } \\
\text { Scale }\end{array}$ & $\begin{array}{c}\mathbf{n} \\
\text { Subyect }\end{array}$ & $\begin{array}{c}\text { n Item } \\
\text { Test \& } \\
\text { Scale }\end{array}$ & $\begin{array}{c}\text { Discrimin } \\
\text { at power }\end{array}$ & $\begin{array}{c}\text { difficulty } \\
\text { index }\end{array}$ & $\begin{array}{c}\text { Item } \\
\text { Validity }\end{array}$ & $\begin{array}{c}\text { Relia- } \\
\text { bility }\end{array}$ \\
\hline Result & 36 & 5 & $.20-.40$ & $.59-.68$ & $.69-.87$ & .69 \\
\hline
\end{tabular}

\section{RESULTS AND DISCUSSION}

\section{Result}

In the results of this study would be explained about the analysis of data on the results of mathematics learning achievement tests. Analysis of data from the results of this test was carried out with the intent to test the hypothesis "There is the influence of the use of Superitem learning models on the subject of quadrilateral on improving student achievement at Muhammadiyah Junior High School 3 Kertasari, Bandung Regency seventh grade second semester. "

To test the hypothesis, the pre-test score and normalized gain results would be analysed, obtained from the experimental class and the control class. To facilitate researchers in analysing data, researchers used the SPSS 16.0 application. This research data was normally distributed and homogeneous. So that, it continued to test the difference in the two averages to see an increase in students learning achievement with learning Superitem. The results of the two average difference test can be seen in table 1 using the SPSS 16.0 statistical application.

Table 2. Average Two Difference Test Results Independent Samples Test

\begin{tabular}{|c|c|c|c|c|}
\hline & & & \multicolumn{2}{|c|}{ Gain } \\
\hline & & & $\begin{array}{l}\text { Equal variances } \\
\text { assumed }\end{array}$ & $\begin{array}{l}\text { Equal variances } \\
\text { not assumed }\end{array}$ \\
\hline \multirow{9}{*}{$\begin{array}{l}\text { Levene's Test for } \\
\text { Equality of Variances } \\
\text { t-test for Equality of } \\
\text { Means }\end{array}$} & \multicolumn{2}{|l|}{$\bar{F}$} & .353 & \\
\hline & \multicolumn{2}{|l|}{ Sig. } & .555 & \\
\hline & \multicolumn{2}{|l|}{$t$} & 4.565 & 4.608 \\
\hline & \multicolumn{2}{|l|}{$d f$} & 60 & 57.153 \\
\hline & \multicolumn{2}{|l|}{ Sig. (2-tailed) } & .000 & .000 \\
\hline & \multicolumn{2}{|l|}{ Mean Difference } & .26897 & .26897 \\
\hline & \multicolumn{2}{|l|}{ Std. Error Difference } & .05891 & .05836 \\
\hline & \multirow{2}{*}{$\begin{array}{l}95 \% \text { Confidence Interval } \\
\text { of the Difference }\end{array}$} & Lower & .15112 & .15210 \\
\hline & & Upper & .38682 & .38583 \\
\hline
\end{tabular}

Based on Table 2, it could be seen that the value of t-count for equal variances assumed was 4.565. Meanwhile, the value of the t-table was 1.6706 with degrees of freedom $(\mathrm{dk})=60$ and a significance level of $\alpha=.05$. Because of $t$-count $>t$-table, then $\mathrm{H} 0$ is rejected. This meant that the increase in mathematics learning achievement abilities of students who got superlearning was higher than students who got conventional learning. Thus, it could be said that super-learning had a positive effect on improving students learning achievement.

This showed that super-learning had a positive effect on improving student learning achievement, because in super-learning there were things as follows: 
1) Basically changing the view of the pedagogy process from the teacher to the students. In conventional teaching, students regard the teacher as an expert in every teaching behaviour, and as a source of knowledge. Whereas in super-learning learning students are required to work alone or in class step by step.

2) In small classroom learning, students are encouraged to collaborate, coordinate their thoughts and efforts to complete their class assignments. While, the teacher acts as a working partner and does not dominate the activities in the class. Thus, the teacher acts more as a motivator, organizer, facilitator, and evaluator.

3) Demand changes in teachers and students from the common roles in traditional learning. The teacher plays an essential role in the formation of cognitive and metacognitive aspects in students, not as the only source of learning. Students act as problem solvers, decision makers, and not as passive listeners.

In general, super-learning learning has a positive influence on improving student learning achievement. Besides the positive results, there are several inhibiting factors that arise during this research activity. These factors include:

1) Requires more time;

2) The lack of prerequisite material mastered by students; and

3) Difficulties in making super-item questions.

\section{Discussion}

Based on the data analysis that had been done, in this section we would discuss the results of the research that had been carried out with regard to the problems that had been formulated. In this study, try out a learning model that is super-learning about improving students learning achievement. During the learning process, the experimental class used super-learning and the control class used conventional learning. From the results of the pre-test and post-test and gain analysis, the following results were obtained:

1) Analysis of the pre-test data aims to measure the initial abilities students have before the learning process. From the results of the pre-test, it was found that student learning achievement was the same between the experimental class and the control class (Darkasyi, Johar, \& Ahmad, 2014; Muhson, 2009).

2) Data gain analysis aimed to see the quality of improvement in students achievement after learning by using super-learning models, from the results of the gain obtained that there was an increase in the average score of students learning achievement tests before and after learning super-items. Apart from it, data gain analysis aims to see differences in the increase in student learning achievement between students who get super-learning and students who get conventional learning. The conclusion was that the increase in students achievement in learning using the super-learning model was higher than students who get conventional learning (Suwardi, 2012).

This showed that super-learning has a positive effect on improving student learning achievement, because in super-learning there are things as follows (Daud, 2012):

1) Basically changing the view of the teaching and learning process from the teacher to the students. In conventional teaching, students regard the teacher as an expert in every teaching behaviour, and as a source of knowledge. Whereas in super-learning learning students are required to work alone or in class step by step.

2) In small classroom learning, students are encouraged to be able to collaborate, coordinate their thoughts and efforts to complete their class assignments. While the teacher acts as a 
372 Maftuh, \& Hidayat. The Effect of Superitem Learning Model on Increasing Students Learning Achievement

working partner and does not dominate the activities in the class. Thus, the teacher acts more as a motivator, organizer, facilitator, and evaluator.

3) Demanding changes in teachers and students from the usual roles in traditional learning. The teacher plays an essential role in the formation of cognitive and metacognitive aspects in students, not as the only source of learning. Students act as problem solvers, decision makers, and not as passive listeners.

In general, super-learning learning has a positive influence on improving student learning achievement. Besides the positive results, there are several inhibiting factors that arise during this research activity. These factors include:

1) Requires more time.

2) The lack of prerequisite material mastered by students.

3) Difficulties in making Superitem questions on students learning achievement in accordance with the taxonomy of SOLO.

\section{CONCLUSION}

Based on the results of the research on the quadrilateral subject using super-learning in the experimental class and conventional learning in the control class, it can be concluded that: "There was a positive influence on the use of super-learning learning models on the quadrilateral subject to improve students achievement at Pangkalan Regency Karawang 2."

\section{REFERENCES}

Darkasyi, M., Johar, R., \& Ahmad, A. (2014). Peningkatan Kemampuan Komunikasi Matematis dan Motivasi Siswa dengan Pembelajaran Pendekatan Quantum Learning pada Siswa SMP Negeri 5 Lhokseumawe. Jurnal Didaktik Matematika, 1(1), 21-34. https://doi.org/10.24815/dm.v1i1.1336

Daud, F. (2012). Pengaruh Kecerdasan Emosional (EQ) dan Motivasi Belajar terhadap Hasil Belajar Biologi Siswa SMA 3 Negeri Kota Palopo. Jurnal Pendidikan Dan Pembelajaran, 9(2), 243-255.

Hajar, Y., \& Sari, V. T. A. (2018). Analisis Kemampuan Pemecahan Masalah Siswa SMK Ditinjau dari Disposisi Matematis. Jurnal Inovasi Pendidikan Dan Pembelajaran Matematika, 4(2), 120-131.

Hartati, L. (2013). Pengaruh Gaya Belajar dan Sikap Siswa pada Pelajaran Matematika terhadap Hasil Belajar Matematika. Jurnal Formatif, 3(3), 224-235.

Martono, N. (2010). Metode penelitian kuantitatif: Analisis Isi dan Analisis Data Sekunder (sampel halaman gratis). RajaGrafindo Persada.

Muhson, A. (2009). Peningkatan Minat Belajar Dan Pemahaman Mahasiswa Melalui Penerapan Problem-Based Learning. Kependidikan.

Permatasari, B. I. (2014). Efektivitas Penerapan Model Pembelajaran Superitem dalam Meningkatkan Pemahaman Konsep Matematika Siswa Kelas X SMAN 11 Makassar. Jurnal Matematika Dan Pembelajaran, 2(1), 136-154. https://doi.org/10.24252/mapan.2014v2n1a10

Pratiwi, R. Y., Sukestiyarno, Y., \& Asikin, M. (2014). Pembentukan Karakter dan Pemecahan Masalah melalui Model Superitem Berbantuan Scaffolding. Unnes Journal of 
Mathematics Education Research, 3(1), 69-74. https://doi.org/10.14710/teknik.v37n2.9011

Rahma, A. N. (2012). Pengembangan Perangkat Pembelajaran Model Inkuiri Berpendekatan Sets Materi Kelarutan Dan Hasilkali Kelarutan untuk Menumbuhkan Keterampilan Berpikir Kritis dan Empati Siswa terhadap Lingkungan. Journal of Education Research and Evaluation, 1(2), 133-138.

Riyani, Y. (2012). Faktor-Faktor yang Mempengaruhi Prestasi Belajar Mahasiswa (Studi pada Mahasiswa Jurusan Akuntansi Politeknik Negeri Pontianak). Jurnal EKSOS, 8(1), 1925.

Suwardi, D. R. (2012). Faktor-Faktor yang Mempengaruhi Hasil Belajar Siswa Kompetensi Dasar Ayat Jurnal Penyesuaian Mata Pelajaran Akuntansi Kelas XI IPS Di SMA Negeri 1 Bae Kudus. Economic Education Analysis Journal, 1(2), 1-7.

Yunus, M., Suyitno, H., \& Waluyo, S. B. (2013). Pembelajaran TSTS Berbasis Konstruktivisme Berbantuan CD Pembelajaran untuk Meningkatkan Kemampuan Komunikasi Matematis Siswa. Unnes Journal of Mathematics Education Research, 2(1), 164-169. 